\title{
Ambidextrous IT Governance Enactment in Healthcare: A comparison between the Swedish and Ugandan setting
}

\author{
Michael Kizito \\ University of Gothenburg \\ michael.kizito@ait.gu.se
}

\begin{abstract}
IT Governance is advocated as a necessary prerequisite for effective digitalization by research and practice alike. Despite this, there are but few studies of IT Governance in the healthcare sector, and even fewer on the enactment of IT Governance. This paper reports on a comparative case study of a Swedish and Ugandan setting on the enactment of ambidextrous IT governance within healthcare. Ambidextrous IT Governance is perceived as governance designed to balance targets of efficiency and innovation, and the study is informed by the resource orchestration logic. The findings show a set of challenges and opportunities in both settings such as complexity in the sharing of information in the Swedish setting and the possibility to leapfrog in the Ugandan. Furthermore, the ambidextrous balancing point and aspired shift differed significantly between the two settings, where the Ugandan setting wanted to rebalance toward exploitation and the Swedish setting toward exploration. The paper concludes with a discussion and a call for future research on ambidextrous IT Governance.
\end{abstract}

Keywords: IT Governance, Resource orchestration, enactment, ambidexterity

\section{Introduction}

The digitalization of society is ushering in new directions for organizations and individuals alike. Core to the notion of digitalization is the parallel utilization of digital technologies for increased efficiency and increased innovation, with new operating models introduced in parallel with continuous enhancements of efficiency $[1,2]$. Within healthcare, notions such as Healthcare IT (HIT) and e-health initiatives have a long tradition $[3,4]$, and the development is expected to continue [5]. With the increased digitalization of healthcare, new challenges emerge concerning how technology should be organized, managed and governed [2,6]. In order to support the digitalization of healthcare, it is imperative that we have the right IT governance mechanisms in place.

The extant literature has identified IT Governance as a pre-requisite for not only organizational success, but also effective, continued digitalization [9]. In this vein, IT Governance refers to decision rights and accountability framework for encouraging desirable behaviours in the use of IT [8], further explicated as a combination of processes, structures and relational mechanisms.

Traditional IT Governance has, however, been criticized for a tendency of bureaucratization and IT function myopia [10], as well as not amply addressing the organization's parallel needs for efficiency and innovation [11]. This need has been studied within the literature concerning organizational ambidexterity, here understood in line with [12] \& [13] as the parallel attainment of exploitation and exploration. Resource orchestration [30] is an emerging stream that has the potential to extend the understanding of resource-based theory (RBT) by explicitly addressing the role of managers' actions to effectively structure, bundle, and leverage organization resources.

Recent additions to this stream of research have called for an increasing dynamic perspective to ambidexterity, i.e. that it is not a stable, fixed state but a continuous configuration of balancing [14,15]. From the dynamic perspective, IT Governance in healthcare needs to move away from only having the senior managers make the key decisions and designing organizational solutions to also empowering the operational managers so as to involve them in the development of ambidextrous strategies, i.e. designed with the intent of dynamically balancing exploitation and exploration. Some IT Governance scholars have posited that senior managers take the central role in designing organizational solutions like structural separation or contextual integration of the exploratory and 
exploitative tasks [16]. On the other hand, [15] state that operational managers use configurational practices to constantly adapt and align to their initiatives' organizational contexts. This allowed them to cope with the persistent tensions in their daily activities which are as a result of simultaneous pursuit of exploitation and exploration. They make the assumption that the senior executives' design choices coupled with organizational systems and processes of the operational managers complement each other in the bid to achieve ambidexterity. The research is guided by the following research question:

How is ambidextrous IT Governance enacted in healthcare organizations in different economic development settings?

This study contributes through comparing two settings where the ambidextrous balancing point between exploitation and exploration is expected to differ, and through offering a unique account of how ambidextrous IT Governance is enacted, operationalized through a resource orchestration lens. The paper is organized accordingly, section 2 discusses the theoretical background, section 3 the method, section 4 results from the study and section 5 is the discussion of the findings and the conclusion.

\section{Theoretical Background}

\subsection{IT governance and Ambidexterity}

The pervasive use of IT as a crucial support for the sustainability and growth of business, creates a critical dependency on IT that demands for a specific focus on IT governance $[7,17,18]$. The digitalization of healthcare has been laden with difficulties in the past [19]. Given the increased pressure to control and monitor costs as well as IT investments making a significant portion of organizations' budgets, effective IT governance is seen as a vital means to ensure returns on IT investments and improve organizational performance. IT governance has been portrayed as a necessary element of successful digitalization in the sense that it is concerned with IT project selection and prioritization issues and how the authority for resources and the responsibility for IT are shared between business partners, IT management and service providers $[8,20]$. Healthcare organization thus need to take IT governance seriously in order to facilitate the digitalization of healthcare.

Effectively realizing IT governance requires a set of IT governance mechanisms to encourage the congruence with organizational mission, strategy, values, norms, and culture [21,22] which in turn promotes desirable IT behaviours and governance outcomes. An organization's IT governance mechanisms are often indicative of the sophistication of its management capability - both IT and business $[3,10]$. Solid IT and business relationships can be considered as one way of realizing successful digitalization. This is because of the trust and shared understanding between the IT and business executives.

IT governance mechanisms can be looked at alongside the lines of ambidexterity research. Studies on ambidexterity focus on the assumption that senior managers are the main decision makers who set the direction, design organizational solutions to address tensions and guide organizational implementation of these solutions [23,24]. These studies portray the operational managers as less influential and peripheral implementers, who are meant to explore or exploit, but are not necessarily involved in the development of ambidextrous strategies and the design of ambidextrous organizational solutions. This view was deemed inaccurate by [25] where they found that operational managers play a proactive role in initiating ambidextrous strategies. Zimmermann et al's [25] argument holds for healthcare organizations in which decision-making cuts across the many stakeholders in healthcare. As such they assume that ambidexterity is a result of senior executives' design choices together with actively shaped organizational systems and processes by the operational managers. Zimmerman et al [15] state that operational managers in successful initiatives used three activities (configurational matching, configurational contrasting and configurational exposure) to adapt and align their initiatives' organizational contexts. The matching and contrasting activities were mainly used to pursue the objectives of ambidexterity in the product while the exposure practice helped in the integration across the various domains.

Since ambidexterity in an organization takes a long time to develop, most of the studies indirectly assume an optimization logic. Organizations that maintain their ambidextrous orientation learn from experience and thus improve their ability to balance exploitation and exploration and this may result into superior long-term gains [26]. Despite the static ambidexterity perspective, the larger exploration/exploitation debate has benefited from dynamic contributions. Formal models of exploration and exploitation [27] build on [12] original model of exploratory choices, exploitative choices and feedback from these choices. Organizations are expected to choose from a set of policy alternatives in formal models while facing uncertainty with regard to each alternative's payoffs [27]. When organizations choose between exploiting 
existing knowledge and exploring new knowledge, they lessen the uncertainty with regard to their available choice set [14].

Ambidextrous IT governance enactment brings into play the collection of activities that are carried out in relation to IT governance configuration. This calls for deliberate effort to ensure control in a behavioural role so that individuals working on IT projects for this case in healthcare act in a way consistent with organizational objectives [28]. Previous research on IT governance had its focus at the corporate level [29] on issues to do with structures, processes and relational mechanisms and these were focused on a static perspective. However, Luger et al [14] develop a dynamic perspective on ambidexterity by clarifying the contingent nature of the ambidexterity/organization performance relationship and by the integration and extension of the ambidexterity and formal modelling perspectives on ambidexterity. Organizations can achieve ambidextrous IT governance by performing a set of actions. This study adopts resource orchestration, an emerging research stream which has the potential to extend the understanding of resource-based theory (RBT) by explicitly addressing the role of managers' actions to effectively structure, bundle, and leverage organizational resources.

\subsection{Resource Orchestration}

Resource orchestration involves structuring the portfolio of resources, bundling of resources to build capabilities and leveraging capabilities in the market place [30]. Structuring includes acquiring, accumulating and divesting of resources, which may involve procuring new resources, improving the existing or decommissioning some resources. Bundling on the other hand is about stabilizing, enriching and pioneering of the existing resources in order to get the best out of the resources. Last but not least Leveraging involves mobilizing, coordinating and deploying of resources. This involves having multidisciplinary teams that can work together to realize the organization's strategic objectives. In healthcare where there are different stakeholders that include clinicians, health IT staff among others, resource orchestration is one approach that can enable coming up with resource-related actions that can inform enactment of ambidextrous IT governance in healthcare organizations. Work on resource management distinguishes between the processes of structuring, bundling, and leveraging from the actual resources being managed [31]. Thus, the processes of resource management refer to what Kraaijenbrink et al [32] call "managerial capabilities." In essence, managers on all levels engage in structuring, bundling, and leveraging processes with the purpose of effectively utilizing the organization's resources to reach an objective such as entering and successfully competing within target markets. This is supported by the empirical tests by Ndofor et al [33] and the results show that managerial actions mediate the resource-performance linkage, thereby providing support for the manager's role in creating a competitive advantage. The actions of the managers must simultaneously address capability strengths and weaknesses in order to realize a competitive advantage [34].

\section{Method}

The study involved dual case studies in two different settings. The rationale behind selecting two different settings was to find comparable case studies where the environmental dynamics differed, since this is regarded as a contingency variable within organizational ambidexterity studies [35,36,37]. According to previous findings, an organization acting in an environment signified by a higher degree of dynamism would need to have a higher emphasis on exploration rather than exploitation [38]. The case study approach was used since it is suitable to study phenomenon in real life context where there is no control of the events that are happening in the healthcare organizations in the different settings [39]. The study done in the Swedish case was carried out in the Västra Götland Region (VGR) in Sweden's second biggest city Gothenburg. VGR was selected on the basis that it is a relatively big organization with 55,000 employees and is a driving force for development in western Sweden [40]. The region collaborates at many levels with academia, the private sector and other public sector organizations.

The study in the Ugandan case was carried out in the capital city Kampala and in two upcountry towns namely Fort portal and Mbale. The capital city was chosen because it is host to the National referral hospital and most of the healthcare organizations both private and public that provide healthcare services. The two upcountry towns were chosen as they are host to regional referral hospitals and so are considered the first point of contact for most patients who require specialised treatment. The healthcare organizations in the capital city and upcountry towns have clinician training schools (Academia) and also work closely with other medical bureaus that provide healthcare support services. Being the flagships of healthcare in the country, they are considered to have adopted the use of health IT. 
In the developed economy context, data collection was carried out in two phases. In the first phase selection of suitable online secondary sources of data and newsletters regarding healthcare initiatives in VGR was done. In the Ugandan case, data was collected from key stakeholders who mainly included health IT professionals and administrators/policy designers. In-depth interviews were conducted in both settings. In the Swedish case, there were 10 informants while in the Ugandan case there were 11 informants (Table 1). In addition to interviews, secondary data was collected from online sources.

Table 1 Informants interviewed in both settings

\begin{tabular}{|c|c|c|c|}
\hline \multicolumn{2}{|c|}{ Swedish context } & \multicolumn{2}{|c|}{ Ugandan context } \\
\hline $\begin{array}{l}\text { Organiza } \\
\text { tion * }\end{array}$ & $\begin{array}{l}\text { Designation of } \\
\text { person } \\
\text { interviewed }\end{array}$ & $\begin{array}{l}\text { Organiza } \\
\text { tion* }\end{array}$ & $\begin{array}{l}\text { Designati } \\
\text { on of } \\
\text { person } \\
\text { interview } \\
\text { ed }\end{array}$ \\
\hline Black & Project Head & Omega & Head IT \\
\hline Yellow & $\begin{array}{ll}\text { Area } & \text { IT } \\
\text { Manager } & \end{array}$ & Beta & $\begin{array}{l}\text { IT } \\
\text { Manager }\end{array}$ \\
\hline Red & $\begin{array}{l}\text { IT strategist/ } \\
\text { Radiology }\end{array}$ & Alpha & $\begin{array}{l}\text { Systems } \\
\text { Administr } \\
\text { ator }\end{array}$ \\
\hline \multirow[t]{6}{*}{ Blue } & $\begin{array}{l}\text { Strategist and } \\
\text { Enterprise } \\
\text { Architect }\end{array}$ & Gamma & IT Head \\
\hline & $\begin{array}{l}\text { Strategic } \\
\text { Architect }\end{array}$ & Phi & $\begin{array}{l}\text { Manager } \\
\text { Medical } \\
\text { Services }\end{array}$ \\
\hline & $\begin{array}{l}\text { eHealth } \\
\text { Expert/Radiolo } \\
\text { gy Nurse }\end{array}$ & Delta & $\begin{array}{c}\text { IT } \\
\text { Officer }\end{array}$ \\
\hline & $\begin{array}{l}\text { Head Care } \\
\text { Digitalization/ } \\
\text { Retired } \\
\text { Medical } \\
\text { Doctor } \\
\end{array}$ & Theta & $\begin{array}{c}\text { IT } \\
\text { Officer }\end{array}$ \\
\hline & $\begin{array}{l}\text { Digitalization } \\
\text { Strategist }\end{array}$ & Lambda & $\begin{array}{c}\text { IT } \\
\text { Head }\end{array}$ \\
\hline & $\begin{array}{l}\text { Chief } \\
\text { Standardizatio } \\
\mathrm{n} \text { officer }\end{array}$ & Kappa & $\begin{array}{c}\text { Com } \\
\text { missioner }\end{array}$ \\
\hline \multirow[t]{2}{*}{ Green } & $\begin{array}{l}\text { Programme } \\
\text { Manager } \\
\text { PICTA }\end{array}$ & Epsilon & $\begin{array}{l}\text { Direct } \\
\text { or } \quad \text { e- } \\
\text { governme } \\
\text { nt } \\
\text { services } \\
\end{array}$ \\
\hline & & & $\begin{array}{l}\text { Health } \\
\text { Lead }\end{array}$ \\
\hline
\end{tabular}

*Names of organizations in table are pseudo names
The interviews focused on issues of governance of IT and resource orchestration activities in healthcare and were conducted following an interview guide. They lasted between 45- 60 minutes. All interviews were recorded and transcribed. A single coder used Thematic analysis [7] for data analysis. In the analysis multiple coding was done focusing on thematic similarity and theoretical coding which helped discover the core category that identified the primary research theme. This framework was used because it focuses on the managers' resource-related actions and how these actions influence organization outcomes such as value creation and the development of competitive advantage.

\section{Results}

The results are presented using the resource orchestration framework by highlighting the resource orchestration activities in the two settings.

\subsection{Structuring}

Structuring refers to the portfolio of resources. IT involves acquiring, accumulating and divesting of an organization's resource portfolio [30]. Findings show that there is a plan to divest old and acquire new IT systems in the Swedish case. Currently, accumulation of resources is what is happening while the planned divesture and acquisition of resources is in plan. The reason for this is that some of the old systems have a lot of information that is useful but are not compatible with the new systems and therefore are not able to share information with other systems as stated by the strategist and Enterprise Architect; "We are trying to build Gartners bimodal-mode 1 getting old systems to work right now that is maintenance. The systems from the 80s have to run and cannot shut down so we have to have the backups and the mode 2 we have the innovation mode. Which is close to what you are looking for." In order to have the old systems share information with the new systems, APIs have been developed in order to have news systems pick information from the old systems though it is not sustainable. There is need for standardization in order to guide the procurement of new healthcare systems that can work together with the financial and administrative systems as further stated by the strategist and Enterprise Architect; "Up until now this has not been done in the architectural way it is only done by getting some money and some people start some project like Sahlgrenska which sometimes doesn't work. So much of my work right now is strategy looking 5 years ahead and trying to start the right things." In the Ugandan case, there has not been 
much in terms of health IT systems and thus acquiring of new systems is possible without a lot of challenges. The issue though is that the financial resources channelled towards this effort are minimal and the acquisition of health IT systems is likely to take a long time. In the Swedish case, county councils have the financial resources to procure what is deemed necessary as opposed to the Ugandan case where the central government has to cater for all the districts in the country and healthcare is not prioritized. As mentioned earlier that lack of sharing of information in the Swedish case has brought about the need for the county councils to work together and share information. This is specifically in the case of a patient who may fall sick when they are away from their resident county council. Currently they have to print out their medical records as they go and visit the primary healthcare facility. This is one of the issues that needs to be addressed with digitalization. The standardization officer in the Western Region of Sweden in support of county councils working together noted that they have developed an information model to help in the interoperability: " $A$ lot of people in healthcare in Sweden and many countries are as well are so reluctant to buy one system but they don't realise what they are buying. They are buying and inheriting an information model that will cause them a lot of trouble when it comes to interoperability because they can't change it. But the step we took is we put the most effort in defining our information model, how the data should be structured. By doing that it is simpler to connect our systems to other systems."

On the part of divesting, the VGR region of Sweden are on course to get rid of the old systems and replace them with new systems seamlessly built into the core system. This was corroborated by the IT strategist and he stated "The next step which we are about to take is to throw out a lot of older systems and reset the healthcare IT with a new core system for general healthcare. Speaking of the diagnostics part of this, I am not sure that we shall exchange the current systems not all of them like for example X-ray we have well-functioning infrastructure but for Laboratory there must be some kind of change".

In the Ugandan case, the private healthcare organizations that have some health IT systems in place have embarked on accumulation, to grow the health information systems network in public healthcare organizations over the country. This is to improve on service delivery so that wherever a patient goes to seek medical assistance within the networked healthcare organizations, they can get help as their medical records will be accessible. The IT manager of one of the private healthcare organization stated that "Information sharing is easier within the network of healthcare organizations-right now MS Dynamics Nav2016 is being used at the headquarters but will be rolled out to the rest of the clinics which are using Navision attain". Much as there are efforts to get the different healthcare organizations systems connected to share information, there is a challenge of bureaucracy in the procurement of new infrastructure required for many of these projects and non-IT savvy clinicians who are supposed to use the system. The health IT officer in support of this stated that "in the bid to realize the sharing of information amongst the various systems comes the need for infrastructure changes which requires approvals and procurement and these processes can be rather long and then later after the implementation has been done, there is need to train the clinicians on the use of the health information system."

In the Swedish case, we see exploitation of actions on the old systems in order to have a clear patient history to help the younger health professionals deliver the necessary treatment and services. At the same time, we see exploration actions especially in so far as having the older and newer systems working together. It calls for innovative ways to have information shared amongst the two systems. Getting the older and new systems to share information suggests enactment efforts in the Swedish case. The other efforts include procuring of new systems that are complaint to an already agreed upon information mode so that there are opportunities to exploit and explore resources in the organizations. The efforts mentioned are considered ways of enactment of ambidextrous IT governance.

In the Ugandan case, given that there are few health information systems which are being adapted and installed in the public the health centres, there are also private health facilities that have their own health information systems. Standards are being worked on to enable sharing of information amongst both the public and private organizations and this suggests there are IT ambidextrous enactment efforts.

\subsection{Bundling}

Bundling refers to the integration of resources to form capabilities. This involves stabilizing, enriching and pioneering with the goal of building capabilities [30]. In the Ugandan case stabilizing activities were noted in the form of improvement of some of the already existing systems by exploiting all the functionality to improve service delivery. This will reduce on the costs incurred by some patients as they move from their places of residence to come to Kampala. The IT head of one of the private healthcare organization stated that "The UgEMR will 
be able to track patients in all districts in the country. This we think will help us achieve our 90-90-90 strategy whereby those who were unable to travel to Kampala to carry out tests or collect their ARVS will now be able to access all these services in their home districts".

In private healthcare organizations there are IT systems that are focused on the clinical, accounting or inventory and these are standalone systems. To realize improved efficiency, there is need to have the systems share information. This is an example of enriching where the current capabilities are extended. This will make it easier to monitor a patient from the time they come into the hospital until the time they leave after treatment. Enriching activities in this case have seen the top management of the private healthcare organizations push for the integration of the existing systems so there can be seamless flow of information between all or most of the available systems. The IT officer at one of the private healthcare organization stated that "The board gave a period of one year to have the accounting and medical records systems share information to enable more transparency in the monitoring of the patients as well as the revenue streams. Furthermore, the board asked the IT department to write a paper on how ICT aligns with the business".

For the Swedish case bundling activities were noted and these were mainly in the areas of enriching and pioneering. Many of the county councils appreciated the need to work together in order to improve their efficiency in serving the patients. This was evident in the way county councils in a given region agreed to procure systems with the same standards in order to share information. This is something that it has not been happening. A patient who needs medical attention out of their county council has to print out their medical records and share them with the physician. With standardized systems this will be solved as stated by the standardization officer "We know how our information is structured. And that is why we could easily not just connect but we could also show the benefits for the patients. It has been happening for the last 12 years in VGR.".

The IT strategist in corroboration of the issue to do with standardization of systems stated that "In the last two to three years there has been a change and we are in the process of buying this core system, and for the core system itself, the top management has put down their foot and said we have to do it properly and this will change the way we deliver hospital IT in the region. There are some goals we should achieve and those we should not and what systems we must get rid of."
Furthermore, an innovation fund was created in Western Sweden to fund innovations that can lead to better delivery of health IT. The political leadership of Västra Götland Region (VGR) apportioned money for that cause and a call was sent out with the aim of attracting ideas for innovation. This is a pioneering activity given that it creates new capabilities. The head of the innovation fund stated that "For the first time we have this opportunity and the politicians have approved 20M SEK this year (2017). We had 177 applications and 39 projects emerged successful. It is not a scientific project but an innovative and developmental project. The county wants to support innovation in the region.". This project will also create some stabilization and enrich the health service delivery process.

\subsection{Leveraging}

Leveraging involves a sequence of processes to exploit the organization's capabilities and taking advantage of specific market opportunities. It includes mobilizing, coordinating and deployment of capabilities to create value. It includes a sequence of processes to exploit the organization's capabilities.

In the Swedish case, a plan is underway to procure a core system which should comply with the information model that was developed to enable sharing of information. There are coordinating activities where the leaderships of the different county councils meet regularly to devise ways of reforming the capability configurations to create value. Mobilizing activities involve having a plan that indicates how to achieve the implementation of the core system in the next 10-15 years as it provides a vision for the capabilities needed to form the needed capability configurations. In this regard, the standardization officer stated "The step we took is we put the most effort in defining our information model, how the data should be structured. By doing that it is simpler to connect our systems to share information."

This will require coordination which is already in progress given that there is now collaboration amongst the county councils. There are also efforts in VGR to use clusters which are their strength to integrate capabilities and at the same time deploy. These clusters are multidisciplinary and the specialists from various sectors come together and meet in their areas to agree on how best ICT can be used to improve efficiency. The clusters are ways of deploying capabilities in order to exploit capability configurations formed by the coordinating processes. In line with this the ICT department head in Gothenburg area stated that "The areas of strength in Gothenburg are not the organizations. The areas of strength require us to go back to the masters. The 
basic idea is that there should be in West Sweden at least one meeting place and one cluster initiative or organization for each and every area. I don't believe in one big IT cluster because ITs are broad and it can become diluted so we need to have a critical mass for each of the area. Therefore, for each area we need to have an organization where people meet, and we have almost succeeded on this."

The governance of health IT in VGR requires streamlining in order to support the realization of the leveraging activities. The available funding to the county councils offers them the prerogative of procuring or implementing whatever they want. This creates a scenario where there seems to be different systems but in actual sense, they are the same but named differently. Thus, as stated by the Strategic Architect, governance of IT is key "The various hospitals developed their own codes in informatics. When there is need to share the same data, there is a lot of work and a lot of it is IT but also people are key. For example, if there are three professors with different opinions, there it comes to governance. It is not about money because you could pour out money but it does not really help. You may develop your own systems but if each of the professors developed their own system there, we would not harvest the fruits. I think that is one thing that is the problem in the whole of Sweden."

Governance of IT from the RO perspective is seen as mobilizing which aims at providing a plan that should be followed through to realize the intended outcomes and this contributes to the efforts of enactment of ambidextrous IT governance.

In the Ugandan case, leveraging activities in the form of mobilization are happening and there are plans geared towards forming the vital capability configurations but the challenge comes in at the implementation. It is affected by a number of factors including but not limited to the inadequate finances, the bureaucracy in procurement of systems and lack of the will to realize the plans on paper. At the national level, an eHealth working group that constitutes of key stakeholders is in practice. This can be considered as deployment and coordination as well. At the organizational level, the board and senior management were in support of each other to see the success of the strategic plan. The IT officer at one of the private healthcare organizations stated that "The board affects the decision of management. If the two are in conflict, it is very likely that plans will not be realized. Another IT officer stated that in order to realize the plans, there is need for new infrastructure but again bureaucratic red tape in the procurement process ends up affecting the implementation."
Furthermore, coordination in terms of bringing together key stakeholders to agree on the best way to deliver health services was evident in the Ugandan case. An eHealth working group was setup and its membership comprised of people from the Ministry of Health (Health professionals), the National Information Technology Authority of Uganda (NITAU) and Academia. The eHealth working group is working out policy guidelines that will guide the operations of the health IT in the country. The health Lead at NITAU stated that "When people have any innovation in health IT, they never consult with NITAU but they go to Ministry of Health which grants them the permission to do whatever they have proposed. Overtime this has led to duplication of the same applications subsequently leading to a ban. With the eHealth group there can be consultations among the eHealth group membership before granting permission to implement any proposed innovation."

In terms of deployment, the Ministry of Health has taken advantage of the District Health Information system 2 (DHIS2) which is available in most of the health centres in the districts of the country. This has improved on the reporting of health-related concerns from the districts on a monthly basis. This enriching effort extends current capabilities to benefit the health centres. These include the number of patients treated in a given month and for which ailments they were treated, and the cases and outbreaks of diseases among others. This helps the ministry in planning for the various districts based on the information they get. At the same time it leads to the avoidance of sending unwanted drugs to certain districts as different districts all have their own unique challenges. The commissioner in charge of Health Information Management systems stated that "With the DHIS2 we have been able to get timely information from the health centres in the districts. This has equally supported the planning process as the technocrats are well informed about what is happening in the various parts of the country. As the Ministry we can then place the right order with the National Drug Authority and National Medical Stores."

IT governance is concerned with the decision rights and accountability framework to achieve desirable behaviour in the use of IT. This description of IT governance suggests that the resource orchestration (RO) perspective is capable of supporting the enactment of IT governance. Using the RO framework, various activities aimed at exploitation and exploration of the existing resources are happening in the healthcare organizations in the two settings. 


\section{Discussion and Conclusion}

The study using the resource orchestration perspective highlighted the different resource orchestration actions carried out by healthcare organizations in order to enact ambidextrous IT governance.

\section{Table 2 Summary of the different resource orchestration actions (challenges and opportunities) in the two contexts}

\begin{tabular}{|c|c|c|}
\hline $\begin{array}{l}\text { Resource } \\
\text { orchestration } \\
\text { actions }\end{array}$ & $\begin{array}{l}\text { Developed } \\
\text { context }\end{array}$ & $\begin{array}{l}\text { Developing } \\
\text { context }\end{array}$ \\
\hline Structuring & $\begin{array}{l}\text { Procurement } \\
\text { process is } \\
\text { underway for a } \\
\text { standardized } \\
\text { healthcare IT } \\
\text { system with } \\
\text { information } \\
\text { sharing among } \\
\text { the different } \\
\text { healthcare } \\
\text { organizations in } \\
\text { the region } \\
\text { Procurement of } \\
\text { more IT systems } \\
\text { to incorporate IT } \\
\text { in areas whose } \\
\text { processes were } \\
\text { not digitized. }\end{array}$ & $\begin{array}{l}\text { Procurement of } \\
\text { basic health } \\
\text { information } \\
\text { systems } \\
\text { Getting to } \\
\text { incorporate IT } \\
\text { in key } \\
\text { processes of the } \\
\text { healthcare } \\
\text { organizations }\end{array}$ \\
\hline Bundling & $\begin{array}{l}\text { Use of APIs in } \\
\text { order to get } \\
\text { critical health } \\
\text { records from the } \\
\text { old IT systems } \\
\text { into the new IT } \\
\text { systems } \\
\text { Creation of new } \\
\text { capabilities in } \\
\text { the region by for } \\
\text { example } \\
\text { adopting a new } \\
\text { information } \\
\text { model } \\
\text { Supporting } \\
\text { innovations from } \\
\text { individuals of } \\
\text { startups through }\end{array}$ & $\begin{array}{l}\text { Use } \\
\text { appropriate } \\
\text { technology to } \\
\text { report } \\
\text { outbreaks given } \\
\text { the low digital } \\
\text { base } \\
\text { Registration of } \\
\text { patients and } \\
\text { storing their } \\
\text { records to } \\
\text { replace the } \\
\text { rudimentary } \\
\text { methods of } \\
\text { writing in } \\
\text { books }\end{array}$ \\
\hline
\end{tabular}

\begin{tabular}{|c|c|c|}
\hline & the science parks & \\
\hline Leveraging & $\begin{array}{l}\text { Bringing } \\
\text { together the } \\
\text { different } \\
\text { specialist } \\
\text { clusters in the } \\
\text { region and tap } \\
\text { into their } \\
\text { professionalism } \\
\text { as a way of } \\
\text { planning for the } \\
\text { future } \\
\text { Piloting of the } \\
\text { different } \\
\text { initiatives that } \\
\text { are outputs from } \\
\text { the science parks }\end{array}$ & $\begin{array}{l}\text { Encouraging } \\
\text { the clinicians to } \\
\text { adopt the use of } \\
\text { IT in their } \\
\text { processes } \\
\text { Having a team } \\
\text { to coordinate } \\
\text { the various } \\
\text { processes in the } \\
\text { organization to } \\
\text { realize the } \\
\text { strategic } \\
\text { objectives }\end{array}$ \\
\hline
\end{tabular}

As noted in previous literature [1,41], IT Governance has displayed a tendency for increased focus on efficiency over time partly due to bureaucracy and formalism being a function of time in large organizations $[42,43]$. Hence, the Swedish setting, with its longer track-record of computerization and its larger installed digital base has geared itself into a position where innovation is not supported by the formal control. This explains the increased demand for shifting the emphasis away from efficiency towards innovation.

In contrast, the Ugandan setting displayed a lower degree of formal control, resulting in a tendency to focus on innovation at the expense of efficiency. A smaller installed digital base, results in easier development and adaption of new solutions, since there is a limited legacy environment to take into account, i.e. less complexity. The strained economic situation in the developing setting makes efficiency gains necessary, whereas we saw initiatives such as the "ban on innovation" being pushed by legislation. Hence, the developing setting displays a contrary stance to the developed setting, in their aspiration to shift the emphasis away from innovation towards efficiency.

On the basis of this, the findings point to a central difference in terms of how ambidextrous IT Governance is enacted in the two different settings. Previous research hypothesizes that the difference in necessary focus on innovation versus efficiency is contingent upon the level of dynamism in the external environment $[13,15]$, yet the findings add to a different interpretation to this relationship. The Ugandan setting is invariably more dynamic than the Swedish one, with more political and geo-political turbulence in place, in parallel with a major 
revamping of the healthcare system itself. At the same time, it has little of the institutional inertia present within the Swedish setting, with a strong installed base of existing solutions acting as deterrents to change. This offers the possibility to further nuance ambidexterity research in two major ways.

First, the assumption that in a dynamic environment, focus on efficiency is meant to attain a certain level of efficiency. This suggests that in the Ugandan setting, if sufficient efficiency is not attained, the organization is not in position to shift its emphasis more towards innovation.

Second, findings point to the issue that the enactment of ambidextrous IT Governance is contingent upon the historical development of governance structures, processes and relational mechanisms [22]. With the increased formalization over time comes an increased tendency to shift the ambidextrous balance towards innovation. This tendency is endogenous in character, and hence challenges the assumption of a direct relationship between the ambidextrous balancing point and environmental dynamism. The shift towards an increased focus on innovation may suggest the effect of either environmental changes or increased/affirmed internal inertia due to formalization of controls [44]. Hence, the casual relationship assumed in the literature is warrant for additional inquiry. Future research should be directed towards better understanding the intricate process of dynamic ambidexterity. As proposed in this paper, the perspective of IT Governance enactment may prove a fruitful avenue through which these issues may be approached.

\section{Acknowledgements}

The author would like to thank SIDA. This work was supported by the SIDA/BRIGHT project 317 under the Makerere-Sweden bilateral research programme 2015-2020. In addition, I would like to thank the HICSS reviewers for their insightful comments that contributed to the improvement of the paper.

\section{References}

[1] Garavaglia, G., Lettieri, E., Agasisti, T. and Lopez, S., 2011. Efficiency and quality of care in nursing homes: an Italian case study. Health care management science, 14(1), pp.22-35.

[2] Gregory, R.W., Keil, M., Muntermann, J. and Mähring, M., 2015. Paradoxes and the nature of ambidexterity in IT transformation programs. Information Systems Research, 26(1), pp.57-80.

[3] Bradley, R. V., Byrd, T. A., Pridmore, J. L., Thrasher, E., Pratt, R. M., and Mbarika, V. W. 2012. " "An Empirical Examination of Antecedents and Consequences of It Governance in U.S. Hospitals," "Journal of Information Technology (27:2), pp. 156-177.

[4] Locatelli, P., Restifo, N., Gastaldi, L., Sini, E., and Torresani, M. 2010. "The Evolution of Hospital Information Systems and the Role of Electronic Patient Records: From the Italian Scenario to a Real Case," Medinfo, pp. 247-251.

[5] Bygstad, B., Hanseth, O., Siebenherz, A., and Øvrelid, E. 2017. "Process Innovation Meets Digital Infrastructure in a High-Tech Hospital, 25 th European Conference on Information Systems (ECIS), Guimarães, Portugal, 2017

[6] Legner, C., Eymann, T., Hess, T., Matt, C., Böhmann, T., Drews, P., Mädche, A., Urbach, N. and Ahlemann, F., 2017. Digitalization: opportunity and challenge for the business and information systems engineering community. Business \& information systems engineering, 59(4), pp.301-308.

[7] Braun, V. and Clarke, V., 2006. Using thematic analysis in psychology. Qualitative research in psychology, 3(2), pp.77-101.

[8] Weill, P., and Ross, J. W. 2004. IT Governance: How Top Performers Manage It Decision Rights for Superior Results. Harvard Business Press.

[9] Debreceny, R.S., 2013. Research on IT governance, risk, and value: Challenges and opportunities. Journal of Information Systems, 27(1), pp.129-135.

[10] Gregory, R.W., Kaganer, E., Henfridsson, O. and Ruch, T.J., 2018. IT Consumerization and the Transformation of IT Governance. MIS Quarterly, 42(4), pp.1225-1253.

[11] Xue, L., Ray, G. and Sambamurthy, V., 2013. Efficiency or Innovation: How Do Industry Environments Moderate the Effects of Firms' IT Asset Portfolios. Published at: MIS Quarterly, 36(2), p.2012.

[12] March, J.G., 1991. Exploration and exploitation in organizational learning. Organization science, 2(1), pp.7187.

[13] Raisch, S. and Birkinshaw, J., 2008. Organizational ambidexterity: Antecedents, outcomes, and moderators. Journal of management, 34(3), pp.375-409.

[14] Luger, J., Raisch, S. and Schimmer, M., 2018. Dynamic balancing of exploration and exploitation: The contingent benefits of ambidexterity. Organization Science, 29(3), pp.449-470.

[15] Zimmermann, A., Raisch, S. and Cardinal, L.B., 2018. Managing persistent tensions on the frontline: A 
configurational perspective on ambidexterity. Journal of Management Studies, 55(5), pp.739-769.

[16] Raisch, S. and Tushman, M.L., 2016. Growing new corporate businesses: From initiation to graduation. Organization Science, 27(5), pp.1237-1257.

[17] Vejseli, S., Rossmann, A. and Connolly, T., 2019, January. IT Governance and Its Agile Dimensions. In Proceedings of the 52nd Hawaii International Conference on System Sciences.

[18] Caluwe, L. and De Haes, S., 2019, January. Board Engagement in IT Governance: Opening Up the Black Box of IT Oversight Committees at Board Level. In Proceedings of the 52nd Hawaii International Conference on System Sciences.

[19] Baugh, C.W., Venkatesh, A.K. and Bohan, J.S., 2011. Emergency department observation units: a clinical and financial benefit for hospitals. Health care management review, 36(1), pp.28-37.

[20] Weill, P., and Ross, J. 2005. "A Matrixed Approach to Designing It Governance," MIT Sloan Management Review (46:2), p. 26.

[21] Ali, S. and Green, P., 2012. Effective information technology (IT) governance mechanisms: An IT outsourcing perspective. Information Systems Frontiers, 14(2), pp.179-193.

[22] Herz, T.P., Hamel, F., Uebernickel, F. and Brenner, W., 2012, January. IT Governance Mechanisms in Multisourcing--A Business Group Perspective. In 2012 45th Hawaii International Conference on System Sciences (pp. 5033-5042). IEEE.

[23] Gibson, C.B. and Birkinshaw, J., 2004. The antecedents, consequences, and mediating role of organizational ambidexterity. Academy of management Journal, 47(2), pp.209-226.

[24] Smith, W.K. and Tushman, M.L., 2005. Managing strategic contradictions: A top management model for managing innovation streams. Organization science, 16(5), pp.522-536.

[25] Zimmermann, A., Raisch, S. and Birkinshaw, J., 2015. How is ambidexterity initiated? The emergent charter definition process. Organization Science, 26(4), pp.11191139.

[26] Raisch, S., Birkinshaw, J., Probst, G. and Tushman, M.L., 2009. Organizational ambidexterity: Balancing exploitation and exploration for sustained performance. Organization science, 20(4), pp.685-695.

[27] Posen, H.E. and Levinthal, D.A., 2012. Chasing a moving target: Exploitation and exploration in dynamic environments. Management Science, 58(3), pp.587-601.

[28] Kirsch, L.S., 1997. Portfolios of control modes and IS project management. Information systems research, 8(3), pp.215-239.

[29] De Haes, S. and Van Grembergen, W., 2009. An exploratory study into IT governance implementations and its impact on business/IT alignment. Information Systems Management, 26(2), pp.123-137.

[30] Sirmon, D.G., Hitt, M.A., Ireland, R.D. and Gilbert, B.A., 2011. Resource orchestration to create competitive advantage: Breadth, depth, and life cycle effects. Journal of management, 37(5), pp.1390-1412.
[31] Sirmon, David G Gove, Steve, Hitt, and A, M. 2008. "Resource Management in Dyadic Competitive Rivalry: The Effects of Resource Bundling and Deployment," Academy of Management journal: AMJ (51:5), pp. 919935.

[32] Kraaijenbrink, J., Spender, J.C. and Groen, A.J., 2010. The resource-based view: a review and assessment of its critiques. Journal of management, 36(1), pp.349-372.

[33] Ndofor, H. A., Sirmon, D. G., and He, X. 2011. "Firm Resources, Competitive Actions and Performance: Investigating a Mediated Model with Evidence from the inVitro Diagnostics Industry," Strategic Management Journal (32:6), pp. 640-657.

[34] Sirmon, D. G., Hitt, M. A., Arregle, J. L., and Campbell, J. T. 2010. "The Dynamic Interplay of Capability Strengths and Weaknesses: Investigating the Bases of Temporary Competitive Advantage," Strategic Management Journal (31:13), pp. 1386-1409.

[35] O'Reilly III, C.A. and Tushman, M.L., 2008. Ambidexterity as a dynamic capability: Resolving the innovator's dilemma. Research in organizational behavior, 28, pp.185-206.

[36] Lavie, D., Stettner, U. and Tushman, M.L., 2010. Exploration and exploitation within and across organizations. The Academy of Management Annals, 4(1), pp.109-155.

[37] Jansen, J.J., George, G., Van den Bosch, F.A. and Volberda, H.W., 2008. Senior team attributes and organizational ambidexterity: The moderating role of transformational leadership. Journal of Management Studies, 45(5), pp.982-1007.

[38] Raisch, S. and Birkinshaw, J., 2008. Organizational ambidexterity: Antecedents, outcomes, and moderators. Journal of management, 34(3), pp.375-409.

[39] Yin, R. 2009. "In L. Bickman \& Dj Rog (Eds.), Case Study Research: Design and Methods." Thousand Oaks, CA: Sage Publications.

[40] VastraGotaland Region. from https://www.vgregion.se/

[41] Boumgarden, P., Nickerson, J. and Zenger, T.R., 2012. Sailing into the wind: Exploring the relationships among ambidexterity, vacillation, and organizational performance. Strategic Management Journal,33(6), pp.587-610.

[42] Magnusson, J., Torell, J., Polutnik, L., and Ask, U. 2017. "Ambidextrous It Governance in the Public Sector: A Revelatory Case Study of the Swedish Tax Authorities," in Information Technology Governance in Public Organizations. Springer, pp. 253-267.

[43] Magnusson, J., Högberg, E. and Sjöman, H., 2019, January. How the West was Lost: Chief Information Officers and the Battle of Jurisdictional Control. In Proceedings of the 52nd Hawaii International Conference on System Sciences.

[44] Urbach, N., Ahlemann, F., Böhmann, T., Drews, P., Brenner, W., Schaudel, F. and Schütte, R., 2019. The impact of digitalization on the IT department. Business \& Information Systems Engineering, 61(1), pp.123-131. 